\title{
STANDARISASI EKSTRAK DIETIL ETER HERBA Oxalis corniculata L.
}

\author{
Herwin, Aminah Hamzah \\ Fakultas Farmasi Universitas Muslim Indonesia \\ Email : herwinfarmasi@gmail.com
}

\begin{abstract}
A research have been conducted about standarisation of diethyl ether ekstrack Oxalis corniculata L. herb from West Sulawesi of Mamuju with a purpose standarisation of diethyl ether ekstrack Oxalis corniculata L. based on specific and non specific parameter. On the way KLT-Bioautography diethyl ether ekstrack with Rf 0.47 value to give activity to Staphylococcus aureus, Streptococcus mutans, Staphylococcus epidermidis, Salmonella thypi, Bacillus subtilis, Escherichia coli, Pseudomonas aeruginosa, Vibrio sp, and Candida albicans. Based on standarisation to result diethyl ether ekstrack obtained that specific parameter to organoleptic fixing ekstrac is green chocolate, typically smelling, bitter feel, jell konsistance, dissolve compound rate of ethanol $95 \%$ counted $31.37 \%$, dissolve compound rate of water counted $24.00 \%$ and non specific parameter to stipulating on water rate counted $16.66 \%$, dusty rate counted $4.16 \%$, sour insoluble dusty rate counted $0.41 \%$, total determination of bacterium $10 \times 10^{2} \mathrm{koloni} / \mathrm{g}$ and total kapang $37 \times 10^{1} \mathrm{koloni} / \mathrm{g}$.
\end{abstract}

Key word : Oxalis corniculata L. Herb, Standarisation of the Diethyl Ether Ekstrack, Antimicrobial

\section{PENDAHULUAN}

Tumbuhan Oxalis corniculata L. (Oxalidaceae) dilaporkan mengandung tannin, linolenik, linoleik, karbohidrat, glikosida, phytosterois, falanoid, asam amino, protein $12.5 \%$, asam sterarat. Tumbuhan ini dikenan dengan berbagai macam nama di oxalis (India), Cu jiang cao (Cina), Weedy oxalis, Yellow oxalis (Inggris) Indonesia belimbing tanah (Mamuju), daun asam kecil (Aceh). (Herbal Tech Industry, 2010; Steenis, 2008). Tumbuhan Oxalis corniculata L. digunakan sebagai obat tradisional untuk digunakan berbagai penyakit seperti demam, flu, diare, radang hati (hepatitis), radang tenggorokan, infeksi saluran kencing, terlambat haid, hipertensi dan neurasthenia (kelemahan badan). (Setiawan, 2006)

Agar khasiat dan stabilitas ekstrak oxalis ini dapat terjamin, maka perlu dipenuhi suatu standar mutu bahan ekstrak, hal ini tidak terlepas dari pengendalian proses, artinya bahwa proses yang terstandar dapat menjamin produk yang terstandar 
mutunya. Dengan adanya bahan baku terstandar dan proses yang terkendali, maka akan diperoleh bahan ekstrak yang mutunya terstandar. (Depkes RI, 1995)

\section{METODE PENELITIAN}

\section{Alat dan bahan}

Alat yang digunakan yaitu seperangkat alat rotavapor, timbangan analitik, oven, cawan petri, cawan porselin, autoklaf, kertas saring bebas abu, desikator, incubator, coloni couter, kertas saring whatman no. 42, laminar air flow.

Bahan yang digunakan herba Oxalis corniculata L., aquadest, Nutrient Agar (merck), Potato Dekstrose Agar (merck), asam sulfat pekat, etanol $96 \%$, etanol $95 \%$, asam klorida pekat, larutan $\mathrm{FeCl}_{3}$, aluminium klorida, asam sulfat pekat $10 \%$.

\section{Pembuatan ekstrak}

Tumbuhan Oxalis corniculata L. yang diperoleh dari Mamuju Sulawesi Barat terlebih dahulu disortasi dan ditimbang sebanyak 300 gram kemudian dimasukkan ke dalam wadah maserasi, lalu ditambahkan etanol 96\% (hingga simplisia tersebut terendam) dan dibiarkan selama 5 hari dengan pengadukan sesering mungkin dalam bejana tertutup dan terlindung dari cahaya. Setelah itu disaring dan ampasnya direndam lagi dengan cairan penyari yang baru. Hal ini dilakukan hingga proses ekstraksi sempurna. Hasil penyarian yang didapat kemudian diuapkan dengan menggunakan rotavapor hingga diperoleh ekstrak etanol kental. Ekstrak etanol kental dipartisi dengan pelarut $n$-heksan, dietil eter dan diuji aktivitas antimikroba secara KLTBioautografi.

\section{Penentuan parameter-parameter} standarisasi

a. Parameter spesifik (Depkes RI, 1980)

1) Penetapan organoleptis ekstrak, meliputi warna, bentuk, bau dan rasa

2) Penetapan kadar senyawa terlarut dalam pelarut tertentu

a) Kadar senyawa yang larut dalam air

Sejumlah 5 gram ekstrak disari selama 24 jam dengan $100 \mathrm{ml}$ air kloroform LP, menggunakan labu bersumbat sambil berkali-kalsi dikocok selama 6 jam pertama 
dan kemudian dibiarkan

selama 18 jam, saring.

Diuapkan $\mathrm{ml}$ filtrat hingga

kering dalam cawan

penguap, residu

dipanaskan pada suhu $105^{\circ} \mathrm{C}$ hingga bobot tetap. Dihitung kadar

dalam persen senyawa yang larut dalam air terhadap berat ekstrak awal.

b) Kadar senyawa yang terlarut dalam etanol 95 $\%$

Sejumlah 5 gram ekstrak disari selama 24 jam dengan 100 etanol $95 \%$ menggunakan labu bersumbat sambil berkali-kali dikocok selama 6 jam pertama dan kemudian dibiarkan selama 18 jam. Disaring cepat dengan

menghindari penguapan etanol, kemudian diuapkan $20 \mathrm{ml}$ filtrat hingga kering dalam cawan penguap yang telah ditara, residu dipanaskan pada suhu $105^{\circ} \mathrm{C}$ hingga bobot tetap. Dihitung kadar

dalam persen senyawa yang larut dalam etanol terhadap berat ekstrak awal.

b. Parameter non-spesifik (Depkes RI, 1980)

\section{1) Penetapan kadar air}

Ditimbang seksama 1 gram ekstrak daslam krus porselen tbertutup yang sebelumnya telah dipanaskan pada suhu $105^{\circ} \mathrm{C}$ selama 30 menit dan telah ditara. Ratakan dengan menggoyangkan hingga merupakan lapisan setebal (5$10 \mathrm{~mm}$ ) dan dikeringkan pada suhu penetapan hingga bobot tetap, buka tutupnya, biarkan krus dalam keadaan tertutup dan mendingin dalam desikator hingga suhu kamar, kemudian bobot tetap yang diperoleh untuk menghitung persentase susut pengeringannya.

\section{2) Penetapan kadar abu}

Ditimbang 2 gram
ekstrak dengan seksama
kedalam krus yang telah
ditara, dipijarkan perlahan-
lahan. Kemudian suhu
dinaikkan secara bertahap
hingga $600 \pm 25^{\circ} \mathrm{C}$ sampai


bebas karbon, selanjutnya didinginkan dalam desikator serta timbang berat abu. Kadar abu dihitung dalam persen terhadap berat sampel awal.

Kadar abu yang tidak larut dalkam asam. Abu yang diperoleh dari penetapan kadar abu, dididihkan dengan $25 \mathrm{ml}$ asam klorida encer $\mathrm{P}$ selama 5 menit, bagian yang tidak larut asam dikumpulkan, saring melalui kertas saring bebas abu, dicuci dengan air panas, disaring dan ditimbang, ditentukan kadar abu yang tidak larut asam dalam persen terhadap berat sampel awal.

3) Penentuan bobot jenis (Depkes RI, 2000)

Bobot jenis ekstrak
ditentukan terhadap hasil
pengenceran ekstrak ( $5 \%$ dan
$10 \%$ ) dalam pelarut tertentu
(etanol) dengan alat
piknometer.

4) Penetuan total bakteri dan total kapang (Depkes RI, 2000)

a) Penentuan total bakteri

Dipipet dengan pipet steril $1 \mathrm{ml}$ ekstrak dari pengenceran $\quad 10^{-4}$,

ditanamkan dalam

medium NA, lalu

diinkubasi pada suhu $37^{\circ} \mathrm{C}$ selama 24 Jam. Kemudian diamati dan dihitung jumlah koloni yang tumbuh dan dikalikan dengan factor pengenceran

b) Penentuan total kapang

Dipipet dengan pipet steril $1 \mathrm{ml}$ ekstrak dari pengenceran $10^{-4}$, ditanam dalam medium PDA, lalu diinkubasi pada suhu $25^{\circ} \mathrm{C}$ selama tiga hari. Kemuydian diamati dan dihitung jumlah koloni yang tumbuh dan dikalikan dengan faktor pengenceran.

c) Uji Kandungan Kimia Ekstrak Aktif

Penapisan golongan kimia ekstrak aktif (Soetarno dan Soediro, 1997; DepKes RI, 2000) diantaranya :

1. Uji Alkaloid

1) Dengan Plat KLT, dimana pada plat ditotolkan ekstrak, lalu disemprotkan 


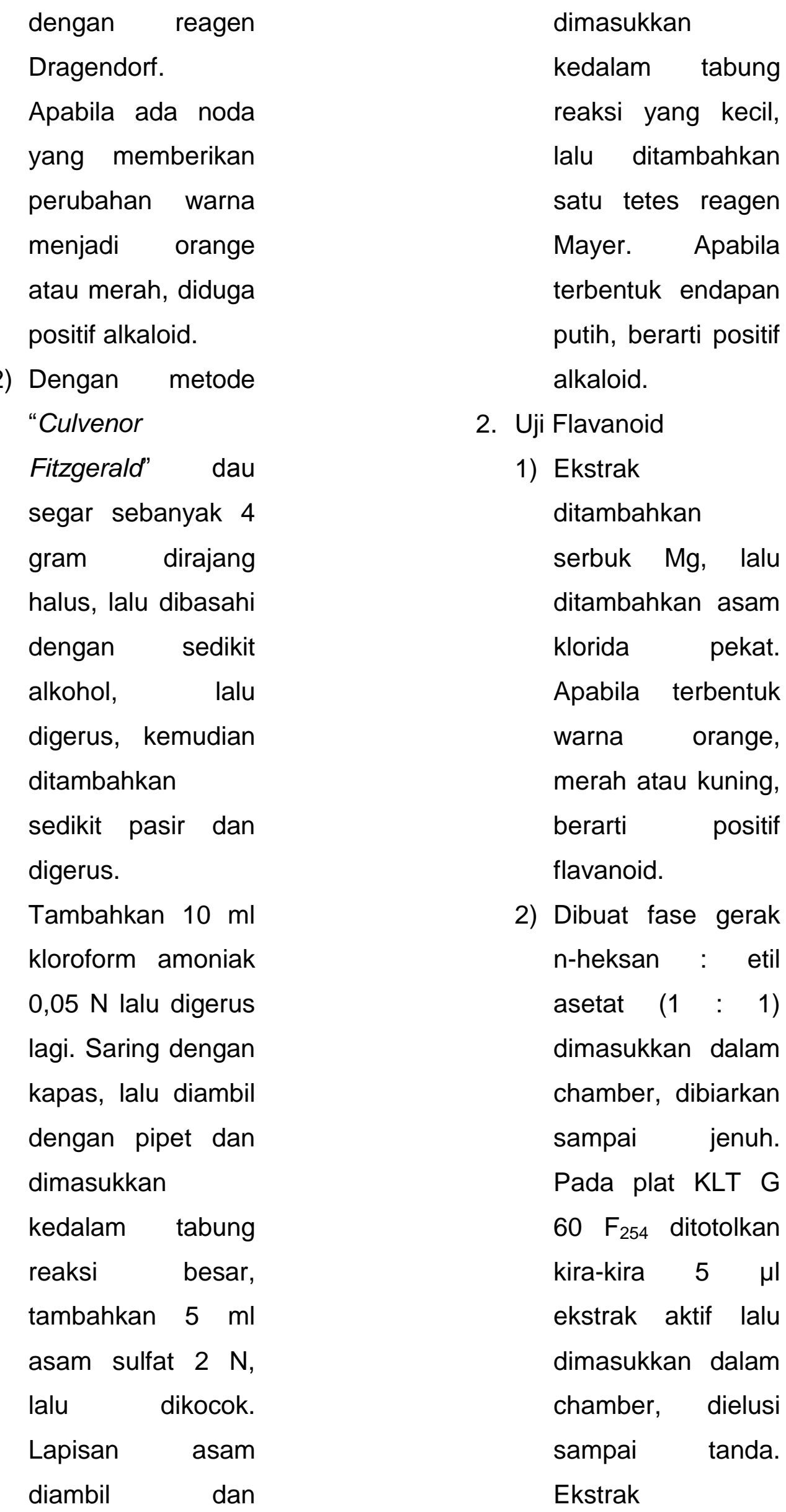




mengandung
flavanoid bebas
bila dilihat dibawah
sinar UV $366 \mathrm{~nm}$
berfluoresensi
hijau/berwarna biru

$\begin{array}{lr}\text { atau } & \text { kuning } \\ \text { dengan } & \text { pereksi } \\ \text { citro borax } & \text { atau } \\ \mathrm{FeCl}_{3}, & \text { pereaksi } \\ \text { benedict } & \text { atau } \\ \text { aluminium } & \text { klorida }\end{array}$

\section{HASIL PENELITIAN}

Tabel 1. Hasil Standarisasi Ekstrak Aktif Ekstrak Dietil Eter Oxalis corniculata L.

\begin{tabular}{llc}
\hline No & \multicolumn{1}{c}{ Parameter } & Hasil \\
\hline & Organoleptis : & \\
& 1. Konsintensi & Kental \\
1 & 2. Warna & Hijau kecoklatan \\
& 3. Bau & Khas \\
& 4. Rasa & Sepat \\
\hline & Kadar senyawa larut dalam : & \\
2 & 1. Etanol 95\% & $31.37 \%$ \\
& 2. Air & $24.00 \%$ \\
\hline 3 & Kadar air & $16.66 \%$ \\
\hline 4 & Kadar abu & $4.16 \%$ \\
\hline 5 & Kadar abu tidak larut asam & $0.41 \%$ \\
\hline 6 & Total cemaran bakteri & $10 \times 10^{2}$ koloni/g \\
\hline 7 & Total cemaran kapang & $37 \times 10^{1}$ koloni/g \\
\hline 8 & Kandungan kimia ekstrak aktif & $(+)$ \\
\hline 9 & -Flavanoid & Profil KLT Flavanoid \\
\hline
\end{tabular}

\section{PEMBAHASAN}

Penelitian ini digunakan sampel berupa herba oxalis corniculata L. segar dimana pelarut sangat mudah berpenetrasi ke dalam herba sehingga zat-zat yang terdapat pada sampel lebih mudah terekstraksi. Maserasi sampel dengan menggunakan etanol karena sifatnya yang mampu melarutkan hamper semua zat, baik zat bersifat polar, semi polar dan non polar serta kemampuannya mengendapkan protein dan menghambat kerja enzim sehingga dapat terhindar proses hidrolisis dan oksidasi (Harborne, 1987; Voight, 1994). Etanol yang digunakan adalah etanol $96 \%$ yang lazim digunakan untuk ekstraksi sampel segar.

Setelah melalui proses maserasi, ekstrak etanol dipekatkan dengan seperangkat rotavapor untuk menguaokan pelarut dan air yang masih tersisa didapatkan ekstrak kental dengan berat konstan(Harborne, 1987). Dasi hasil 
maserasi diperoleh $23 \%$ dari beras segarnya.

Setelah diperoleh ekstrak kental, dipartisi dengan menggunakan pelarut $n$-heksan dan dietil eter dan diuji aktivitasnya secara KLTBioautografi sehingga diperoleh ekstrak dietil eter sebagai ekstrak aktif yang menghambat pertumbuhan mikroba Staphylococcus aureus, Streptococcus mutans, Staphylococcus epidermidis, Salmonella thypi, Bacillus subtilis, Escherichia coli, Pseudomonas aeruginosa, Vibrio sp, dan Candida albicans. Ekstrak aktif (ekstrak dietil eter) dilakukan penetapan standar mutu dan kandungan kimia ekstrak aktif. Persyaratan mutu ekstrak aktif meliputi parameter standar umum dan parameter standar spesifik. Standarisasi ini dimaksudkan agar dapat menjamin bahwa produk ekstrak mempunyai nilai parameter tertentu yang konstan (Depkes RI, 2000).

Pada pemeriksaan organoleptik ekstrak meliputi ekstrak berkonsistensi kental, berwarna hijau kecoklatan, berbau khas dan rasa sepat. Penentuan organoleptik ini merupakan parameter spesifik yang ditentukan dengan tujuan untuk pengenalkan awal secara sederhana dan subjektif.
Kadar senyawa yang terlarut dalam etanol $95 \%$ sebanyak $31.37 \%$, kadar senyawa larut air sebanyak 24.00\%. Ini berarti bahwa ekstrak lebih banyak larut dalam etanol dibandingkan dalam air. Kadar zat terlarut ini merupakan uji kemurnian ekstrak yang dilakukan untuk mengatahui jumlah terendah bahan kimia kandungan ekstrak yang terlarut dalam pelarut tertentu. Untuk syarat kemurnian dari simplisia maupun ekstrak, minimum harus dilakukan uji penetapan kadar zat terekstraksi dalam air dan etanol (Soetarno dan Soediro, 1997). Parameter non spesifik terhadap penetapan kadar air sebanyak 16.66\%, kadar abu sebanyak $4.16 \%$, kadar abu tidak larut asam $0.41 \%$.

Pengujian cemaran mikroba merupakan salah satu uji untuk syarat kemurnian ekstrak. Ini mencakup penentuan jumlah mikroba yang diperbolehkan dan untuk menunjukkan tidak adanya bakteri dan kapang tertentu dalam ekstrak. Pada ekstrak terdapat cemaran bakteri $10 \times 10^{2}$ koloni/g ini berada dibawah batas maksimum yaitu $10^{6}$ menurut SK Dirjen POM No : 03726/B/SK/VII/89 tentang batasan maksimum mikroba dalam makanan (ekstrak). 
Pada cemaran kapang diperoleh $37 \times 10^{1} \mathrm{koloni} / \mathrm{g}$ berada dibawah batas maksimum berdasarkan standar badan POM yaitu $10^{4}$ koloni/g.

\section{KESIMPULAN}

1. Berdasarkan parameter spesifik yaitu secara organoleptik ekstrak berkonsistensi kental, berwana hijau kecoklatan, bau khas, rasa sepat, kadar senyawa yang terlarut dalam etanol $95 \%$ sebanyak $31.37 \%$, kadar senyawa larut air sebanyak $24.00 \%$.

2. Parameter non spesifik terhadap penetapan kadar air sebanyak $16.66 \%$, kadar abu sebanyak 4.16\%, kadar abu tidak larut asam sebanyak $0.41 \%$ dengan total cemaran bakteri $10 \times 10^{2}$ koloni/g dan kapang $37 \times 10^{1}$ koloni/g berada dibawah batas maksimum yaitu bakteri $10^{6}$ dan kapang $10^{4}$ koloni $/ \mathrm{g}$ menurut SK Dirjen POM No : 03726/B/SK/VII/89 tentang batasan maksimum mikroba dalam ekstrak.

3. Ekstrak dietil eter sebagai ekstrak aktif menghambat pertumbuhan mikroba Staphylococcus aureus, Streptococcus mutans, Staphylococcus epidermidis, Salmonella thypi, Bacillus subtilis,
Escherichia coli, Pseudomonas aeruginosa, Vibrio sp, dan Candida albicans dengan nilai $\mathrm{Rf} 0.47$.

\section{DAFTAR PUSTAKA}

Kathiriya A.K.,, Kuntal D., Joshipura M., and Mandal N., 2010. "Oxalis corniculata Linn. The Plant of Indian subtropics", Herbal Tech Industri, India

Departemen Kesehatan RI, 1980. "Materia Medika Indonesia", Jilid IV, Jakarta

Departemen Kesehatan RI, 1995. "Farmakope Indonesia", Edisi IV, Jakarta

Departemen Kesehatan RI, 2000. "Parameter Standar Umum Ekstrak Tumbuhan Obat", Edisi I, Dirjen POM Direktorat Pengawasan Obat Tradisional, Jakarta

Harborne, J.B., 1987. "Metode Fitokimia Penuntun Cara Modern Menganalisa Tumbuhan", Cetakan II, Diterjemahkan oleh Padinawinata K., dan Soediro I., Penerbit IPB Bandung.

Steenis, Van.C.G.G.J. dkk. 2008. Flora. PT. Pradnya Paramita: Jakarta .

Soetarno S., dan Soediro I.S., 1997. "Standarisasi Mutu Simplisia dan Ekstrak Bahan Obat Tradisional", Presidium Temu IImiah Nasional Bidang Farmasi

Voight R., 1994. "Buku Belajar Teknologi Farmas", Diterjemahkan oleh Noerono S., UGM Press, Yoryakarta 